\title{
The synergy between employment policies and cooperatives with regard to new forms of work. An overview based on Spanish constitutional law*
}

(La sinergia entre las políticas de empleo y las cooperativas respecto a las nuevas formas de trabajo. Una perspectiva desde el Derecho Constitucional español)

\author{
Santiago Larrazabal Basáñez ${ }^{1}$
}

University of Deusto (Spain)

Summary: 1. Introduction. 2. The promotion of employment and cooperatives in the Spanish Constitution. 2.1. Fostering employment. 2.2. The promotion of cooperatives. 3 . The effects of the crisis on the protection of social rights and the guiding principles of social and economic policy. 4 . The promotion of cooperatives as a means to support employment policies under the Spanish legal system. 5. Conclusions. 6. References.

Sumario: 1. Introducción. 2. La promoción del empleo y de las cooperativas en la Constitución española. 2.1. El fomento del empleo. 2.2. La promoción de las cooperativas. 3. Los efectos de la crisis sobre la protección de los derechos sociales y de los principios rectores de política social y económica. 4. La promoción de las cooperativas como vías de apoyo a las políticas de empleo en el ordenamiento jurídico español. 5. Conclusiones. 6. Bibliografía.

Abstract: This text explains how active employment policies and cooperatives are perfectly suited to fulfil the mandates outlined in the 1978 Spanish Constitution in relation to the promotion of cooperatives (Article 129.2), and

* This paper is part of the following research project: 'Cooperatives as an employment policy instrument to address new challenges in the world of work' (CIPERMT) (file number RTI2018-097715-B-100). This project has been financied by the Spanish Ministry of Science, Innovation and Universities, the State Bureau of Investigation and the European Regional Development Fund within the call for proposals for 2018 on Research and Developement Projects to generate knowledge and Research, Development and Innovation Projects about Research Challenges.

1 Ph.D., Lecturer in Constitutional Law and member of the 'Cooperativism, taxation, promotion, labour relations and social protection' research group. E-mail: santiago. larrazabal@deusto.es 
to policies oriented towards full employment (Article 40.1), which fall under the overall protection of social rights. After analysing the provisions contained in these two articles, details are provided as to how the economic crisis and the strict balanced budget policies that ensued have also weakened the constitutional protection of social rights, with the adoption of regressive measures whose compatibility with the Constitution has been accepted by the Spanish Constitutional Court (despite divided opinions among the Court's members). Finally, an analysis is conducted of the options available within the Spanish legal system to protect and encourage cooperative societies. It is then argued that cooperatives can be a very useful instrument to create employment, even within the most innovative and dynamic sectors of the economy. These sectors include, for example, the collaborative economy (which includes the digital economy), the 'white economy', the 'green economy' and the 'circular economy'.

Keywords: Employment policies; Cooperatives; New forms of work; Social rights; Spanish Constitutional Law.

Resumen: El texto pretende explicar cómo las políticas activas de empleo y las cooperativas encajan perfectamente el desarrollo de los mandatos que la Constitución Española de 1978 establece en relación con el fomento de las cooperativas (art. 129.2) y con una política orientada al pleno empleo (art. 40.1), en el marco de la protección de los derechos sociales en general. Tras analizar el contenido de estos dos artículos, se explica cómo, sin embargo, la crisis económica y las severas políticas de equilibrio presupuestario impuestas tras ella, han debilitado también la protección constitucional de los derechos sociales, con la adopción de medidas regresivas cuya compatibilidad con la Constitución ha sido aceptada por el Tribunal Constitucional español (aunque con división en el seno del propio Tribunal). Finalmente, se estudian las posibilidades que el ordenamiento jurídico español ofrece para proteger e impulsar a las sociedades cooperativas y cómo éstas, fieles siempre a sus principios cooperativos, pueden ser un instrumento muy útil para crear empleo, incluso en los sectores más novedosos y dinámicos de la economía como, por ejemplo, la economía colaborativa - y dentro de ella, la economía digital一, la «economía blanca», la «economía verde», «la economía circular».

Palabras clave: Políticas de empleo; Cooperativas; Nuevas formas de trabajo; Derechos sociales; Derecho Constitucional español. 


\section{Introduction}

The synergy between active employment policies ${ }^{2}$ and cooperatives fits perfectly with the mandates outlined in the 1978 Spanish Constitution regarding policies directed towards full employment (Article 40.1) and the promotion of cooperatives (Article 129.2), respectively. Firstly, this paper analyses the legal framework of these two articles, which are part of two different areas of the Constitution. The policies aimed at full employment (Article 40.1) are contained in the section that could broadly be called 'social rights', which also includes the regulation of the so-called 'principles governing social and economic policy'. The promotion of cooperative societies (Article 129.2) belongs to the so-called 'Economic Constitution', regulated mainly by Title VII, relating to Economy and Finance.

Secondly, an explanation is given of how the deep economic crisis experienced in recent years has also weakened the constitutional protection of social rights and, therefore, the principles governing social and economic policy. These principles include employment, to the extent that controversial, clearly regressive measures were adopted in these areas under the shadow of the economic crisis and the severe policies required for a balanced budget. This even led to a reform of Article 135 of the Spanish Constitution in 2011 which was implemented within a very short period of time. ${ }^{3}$ The constitutionality of these measures was endorsed by the Spanish Constitutional Court.

Thirdly, the paper examines the options provided for in the Spanish legal system to protect and encourage cooperatives. Since cooperatives can be an ideal instrument for creating high-quality employment, their values are perfectly matched with a social model that promotes social rights and helps overcome the painful social cuts caused by the economic crisis and adjustment policies.

2 Under Spanish law, active employment policies are defined as 'the package of services and programmes aimed at providing guidance, employment and training for employment seeking to improve employability of unemployed people, on either an employed or a self-employed basis, the maintenance of employment, the professional development of employees and the promotion of entrepreneurship and the social economy' (Article 36.1 of Royal Legislative Decree 3/2015, of 23 October, which approves the Consolidated Text of the Employment Act (published in the Official Gazette, hereinafter, BOE, No. 255, of 24 October).

3 Reform of Article 135 of the Spanish Constitution, of 27 September, 2011 (BOE no. 233, of 27 September, 2011). On this question see, for example, LÓPEZ GARRIDO, D. (Dir.), (2013). 


\section{The promotion of employment and cooperatives in the Spanish constitution}

\subsection{Fostering employment}

Article 40.1 of the Spanish Constitution states that 'the public authorities shall promote favourable conditions for social and economic progress and for a more equitable distribution of personal and regional income within the framework of a policy of economic stability. They shall devote special attention to carrying out a policy directed towards full employment'.

This article is included in Chapter III of Title I of the Constitution, on the principles governing social and economic policy, and is complementary to Article 35 of the Constitution, which contains the right and duty of Spaniards to work, ${ }^{4}$ although Article 35 is in the second section of Chapter II of Title I of the Constitution. ${ }^{5}$ The relationship between Articles 35 and 40.1 of the 1978 Spanish Constitution was established by the Constitutional Court from early case law (specifically as of Judgment 22/1981, of 2 July), ${ }^{6}$ as the synthesis of both the individual and collective aspects of the same concept.

4 The full text of Article 35 of the Constitution reads:

1. 'All Spaniards have the duty to work and the right to employment, to free choice of profession or trade, to advancement through their work, and to sufficient remuneration for the satisfaction of their needs and those of their families; moreover, under no circumstances may they be discriminated against on account of their gender.

2. The law will regulate a Workers Statute.'

5 These types of provisions have precedents in Spanish constitutional history and also in comparative law, in international law and in European Union law. For example, in Article 46 of the Spanish Constitution of the Second Republic of 1931 and in Articles 35 et seq. of the 1947 Italian Constitution and 58 et seq. of the 1976 Portuguese Constitution. For its part, international law must take into account Article 6.2 of the International Covenant on Economic, Social and Cultural Rights, which refers to full and productive employment; Article 1.1 of ILO Convention No. 122, which states that ILO members shall declare and pursue, as a major goal, an active policy designed to promote full, productive and freely chosen employment. These provisions have precedents within the scope of European Union law in Article 3.3 of the Treaty on European Union and Article 147 et seq. of the Treaty on the Functioning of the European Union, both of which refer to employment.

6 This Judgment states that the right to work is not exhausted in the freedom to work; it also involves the right to a job and, is twofold, as it is both individual and collective, as recognised in Articles 35.1 and 40.1 of the Spanish Constitution, respectively. Its individual aspect is embodied in the equal right of all to a certain job if they are appropriately qualified for it, and in the right to continuity and stability in employment, that is, to remaining employed unless there is just cause for dismissal. In its collective dimension, the right to work also involves a mandate for the public authorities to carry 
The problem posed by the provisions in Article 40.1 is that their constitutional guarantees are quite weak. In contrast, the rights provided for in Article 35 are better protected: Title I of the Constitution, under the heading 'Concerning Fundamental rights and duties', clearly differentiates between civil and political rights (which have greater constitutional protection), granted in Chapter II, Section 1, on the one hand; and economic and social rights, mostly contained ${ }^{7}$ in Chapter II, Section 2 (including Article 35, which have a lower degree of protection). ${ }^{8}$ However, Article 40.1 of the Constitution, which refers to full employment, enjoys even less protection than Article 35 and for that reason it does not appear in Chapter II, but in Chapter III of Title I, under the heading 'Principles governing Economic and Social Policy'. ${ }^{9}$

According to the provisions in Article 53.3 of the Constitution, the recognition, respect and protection of these guiding principles will inform positive law, judicial practice and the actions of the public authorities, but they can only be invoked before ordinary Courts under the regulations which develop them. In other words, they require legislative development. As TEROL BECERRA ${ }^{10}$ argued, the main problem lies in the difficulty in making them to be enforceable by the authorities. ${ }^{11}$

out a policy of full employment; otherwise the exercise of the right to work by one part of the population entails the denial of that same right for another part of it (Constitutional Court Judgment —hereinafter, STC - 22/1981, of 2 July, Eighth legal ground. This argument was reiterated in Constitutional Court Judgments 119/2014, of 16 July and 104/2015, of 28 May.

7 An exception to this are some social rights which are specially protected and provided not in Section 2 of Chapter II like the rest of the social rights, but in Section 1. These include, for example, the right to education (Article 27), the right to strike and the right to freely join a trade union (Article 28). Given their location, they enjoy the same protection as civil and political rights, that is, the maximum level of protection granted by the Spanish Constitution.

8 BONET PÉREZ, J. / ALIJA FERNÁNDEZ, R.A. (2016); ESCOBAR ROCA, G. (2012, 486); GARCÍA SCHWARZ, R. (2011, 81); PISARELLO, G. (2007, 43 and seq.; 2009, 44); MONEREO PÉREZ, J.L. (2017, 706 et seq.); PONCE SOLÉ, J. (2017, 95); TORROJA MATEU, H. (2016, 147-148).

9 On the guiding principles of social and economic policy, see, for example: BAYLOS GRAU, A. (2003, 13-54); BELORGEY, J.-M. (2016, 263); EMBID IRUJO, A.(2009); GARCÍA HERRERA, M.A. (2003-2004, 292); ESPINOSA DE LOS MONTEROS, J. I ORDÓÑEZ, J. (coord.) (2013); JIMENA QUESADA, L. (2016, 205); NOGUERA FERNÁNDEZ, A. / GUAMÁN HERNÁNDEZ, A. (2014); PÉREZ LUÑO, A.E. (2013, 23-31); PONS CARMENA, M. (2015); PRESNO LINERA, M.A. (2010); TENORIO, P. (2012, 257 et seq.); TEROL BECERRA, M. (2009a, 2011 and 2012); VALDÉS DAL-RÉ, F. (2016, 110).

10 TEROL BECERRA, M. (2012, 45); TEROL BECERRA, M. / JIMENA QUESADA, L. (2014).

11 ABRAMOVICH, V. I COURTIS, CH. (2004, 128 et seq.); BARRERO ORTEGA, A. (2017, 69-72); CARMONA CUENCA, E. (2017, 1215); CUBERO MARCOS, J.I. (2017, 123-130); JIMENA QUESADA, L.(2014, 13-28); LARRAZABAL BASAÑEZ, S. $(2009,186)$. 
However, other authors are more optimistic, as they believe that they go beyond mere points in a manifesto ${ }^{12}$ and that legislators do not have full discretion when carrying them out. ${ }^{13}$

Even the Spanish autonomous Regions have sometimes been more sensitive than the central government in terms of protecting social rights. ${ }^{14}$ When their Statutes of Autonomy were reformed in 2006, they included declarations of rights. The Spanish Constitutional Court has accepted the insertion of rights into the new Statutes of Autonomy, ${ }^{15}$ notably including those concerning social aspects (for example, those referring to education, housing, healthcare, adoption of positive actions for the benefit of disadvantaged groups, freedom of choice of doctor and health centre, right to basic income, etc.). ${ }^{16}$

\subsection{The promotion of cooperatives}

The promotion of cooperatives is provided for in Article 129.2 of the Constitution, which is not in Title I (related to fundamental rights and duties), but in Title VII (related to Economy and Finance), which includes most of the provisions of what has been called the 'Economic Constitution'. Article 129.2 reads as follows: 'The public authorities shall efficiently promote the various forms of participation within companies and shall encourage cooperative societies by means of appropriate legislation. They shall also establish means to facilitate access by the workers to ownership of the means of production. ${ }^{17}$

As GADEA, SACRISTÁN and VARGAS 18 noted, the Spanish Constitution incorporated the most modern European trends in European law regarding cooperatives. It placed them in the proper context of participation, unlike other Constitutions such as the Italian Constitution. Article 45 of the Italian Constitution adopted a more classic stance by recognising the social role of cooperatives with a mutual character and

12 BAYLOS GRAU, A. (2003, 13-54); MONEREO PÉREZ, JL $(2016,95)$, RUIZ-RUICO RUIZ, G. (2016, 30-37).

13 TAJADURA TEJADA, J. (2002, 443 et seq.).

14 TEROL BECERRA, M. (2009b, 129); TORNOS MÁS, J. (2017, 45)

15 Constitutional Court Judgments 247/2007, of 12 December (on the Statute of Autonomy of the Valencian Region) and 31/2010, of 28 June (in relation to the Statute of Autonomy of Catalonia).

16 BARRERO ORTEGA, A. (2017, 73-74); VALCÁRCEL BUSTOS, M. (2018, 341-372).

17 PRADOS DE REYES, J. / VIDA SORIA, J. (1998, X, 89-119).

18 GADEA, E. / SACRISTÁN, F. / VARGAS, C. (2009, 37). 
no private speculation purposes. ${ }^{19}$ In this regard, the Spanish Constitutional Court has also 'given its blessing' — to put it graphically - to legal regulations of cooperatives that tend to overcome a rigidly mutualist conception. ${ }^{20}$

As DE LUIS ESTEBAN argued, ${ }^{21}$ the Constitution does not seek a neutral legislative scenario for cooperatives, but clearly opts to support them and create a favourable framework for their development. Therefore, the State must not remain passive with regard to the cooperative environment, since it has a constitutional mandate to foster and promote it. As a result, any regulatory developments (from commercial, administrative/fiscal perspectives, etc.) that could be considered regressive in terms of participation in companies or that would might hinder or distort the operation of cooperatives in any way would be unconstitutional.

The legislative development of cooperatives in Spain has taken place, above all, through the laws of the Spanish autonomous regions. Although laws on Cooperatives exist for application throughout Spain, 22 the Statutes of Autonomy of the various regions have assumed regulatory jurisdiction over cooperatives and mutual societies not integrated in the Social Security system. While the regions are required to observe the applicable commercial legislation that falls under the jurisdiction of the State, regional laws have a central role in the regulation of cooperativism in Spain.

Practically all the autonomous regions have their own Cooperatives Law. The Basque Country was a pioneer in this respect, given the importance that cooperatives have in its industrial fabric. This regulatory situation on cooperatives in Spain was accepted by the Constitutional Court at a very early stage. In STC 72/1983, of 29 July, the Constitutional Court dismissed an appeal against the alleged unconstitutionality of pioneering Basque Law 1/1982, of 11 February, on cooperatives,

19 In comparative law, the study by $\mathrm{FICl}(2015,78)$ bears review. This author recalled how cooperatives as institutions have been welcomed in Europe, both within various constitutions and within ordinary legislation. In the constitutional sphere a number of articles of the Italian Constitution are worth noting, namely Articles 43.4, 45, 60.3, 61.2 and 3, 65, 2 d), 80 b) and f), 82.4, 85, 94.2., 97. 1 and 2 d), 136.3 b) and 288 f). In ordinary legislation sphere, the more remarkable examples are Portuguese legislation (Law 30/2013 of 8 May, on the grounds for the social economy) and French legislation (Law no. 387/2014, of 21 July, on the social and solidarity-based economy).

20 STC 155/1993, of 3 May.

21 DE LUIS ESTEBAN, JM $(1985,92)$.

22 Law 27/1999, of 16 July, on cooperatives (BOE -Official Gazette- no. 170, of 17 July, 1999). 
and confirmed the jurisdiction authority of the autonomous regions regarding cooperatives. ${ }^{23}$

I will now discuss cooperatives as an instrument for the promotion of employment in times of crisis. The recent crisis has resulted in a significant reduction in the protection of social rights and the guiding principles of social and economic policy.

\section{The effects of the crisis on the protection of social rights and the guiding principles of social and economic policy}

The impact of the global economic crisis that began in 2008 led to severe cuts in the benefits derived from some historically recognised social rights. This caused a strong decline in the levels of protection linked to some of the guiding principles of social and economic policy (as covered by the Spanish constitution regarding employment, health benefits, housing policy, pensions, etc.). The legal doctrine has often considered this regression in the protection of social rights to be a consequence of the crisis and of the 'sacred' principle of a balanced budget. ${ }^{24}$

Some of the Spanish Constitutional Court's Judgments had already warned that the duty to provide social assistance must be interpreted 'in connection with economic circumstances, the availability at each given time and the needs of the various social groups'. ${ }^{25}$ Therefore, when cuts and the legislative measures were later applied that overturned some well-established social rights, the Constitutional Court endorsed their constitutionality. JIMENA QUESADA ${ }^{26}$ described how STC 8/2015 of 22 January endorsed the constitutionality of the labour reform ${ }^{27}$, which re-

23 This case law has been maintained over time and was made apparent in STC 291/2005, of 10 November, which compiled the case law of the Court on this matter.

24 ABDELHAMID A. / AGUDO, M. (2018); AGUDO ZAMORA, A. (2016, 33-35); ANSUÁTEGUI ROIG, FJ (2014, 36-40); AÑÓN ROIG, M.J. (2016, 58-60); BALAGUER CALLEJÓN, F. (2013, 449-454); CALVO GARCÍA, M. (2013, 92-93); DONAIRE VILLA, F.J. (2018); GAMBINO, S. (2017); GORDILLO PÉREZ, L.I. (2014, 47; 2015); JIMENA QUESADA, L. (2016, 127; 2017, 25); LANGFORD, M. (2009); MARTÍNEZ DE BRINGAS, A. (2018, 156-162); MONEREO PÉREZ, J.L. (2013, 13-66); PONCE SOLÉ, J. (2013); QUEIROZ, C. (2006); REQUEJO RODRÍGUEZ, P. (2015, 430); RODRIGO, A. (2016, 76); SANZ GÓMEZ, R. (2016, 477-490); SOTO LOSTAL, S. (2013, 55; 2017, 25); TEROL BECERRA, M. (2012); TUSHNET, M. (2008); VALDÉS DAL-RÉ, F. (2018, 21-49).

25 STC 65/1987, of 21 May, and STC 134/1987, of 21 July.

26 JIMENA QUESADA, L. (2017, 115-116, 123).

27 Law 3/2012, of 6 July, on urgent measures for the reform of the labour market. 
ferred to STC $119 / 2014$, of 16 July, ${ }^{28}$ contained a private vote disagreeing with the position held on this matter by the majority of the Court, subscribed to by three judges: ' ... STC 119/2014 provided a new reasoning in the doctrine of this Court: a new constitutionality standard, which the judgment of the majority has now accepted and integrated as being normal. This can be succinctly — but not simplistically- expressed by saying that these resolutions, among others, have raised the adverse economic scenario exceptionally experienced by Spanish citizens for years to the category of constitutionality standard. In other words, these judgments have used the economic crisis as a parameter for the assessment on the constitutionality of the limiting measures of the rights provided for in Chapter II of Title I of the Spanish Constitution, not to mention the guiding principles of the social and economic policy of Chapter III.'

Unfortunately, this trend in case law has been confirmed in subsequent judgments. For example, in STC 49/2015, of 5 March, ${ }^{29}$ the Constitutional Court endorsed by a majority that the upward adjustment of pensions according to the Consumer Price Index should be suspended (four judges voted against and issued a private vote in disagreement). This ruling held that the decision did not violate Article 50 of the Constitution, which provides for the upward adjustment of pensions. And in STC 95/2015, of 14 May, referred to the same provision, the Court again endorsed the suspension. In STC 216/2015, of 22 October 22,30 it gave its blessing to a cessation of measures to promote rental housing and make the rental market more flexible. Along these lines, STC 139/2016, of 21 July, ${ }^{31}$ with three dissenting votes and their corresponding particular votes, also endorsed that irregular migrants be excluded from healthcare.

However, in comparative constitutional case law, other options have been defended that are very different from this highly compre-

28 This STC dismissed another unconstitutionality challenge brought against the Law on the reform of the labour market.

29 This Constitutional Court Judgment ruled by majority that Royal Decree-Law 28/2012, of 30 November, on measures for consolidating and securing the Social Security system, was constitutional.

30 The Constitutional Court (with a dissenting private vote) dismissed the unconstitutionality challenge brought against Additional Provision 2 of Law 4/2013, of 4 June, on measures to promote rental housing and to make the rental market more flexible. Law 4/2013 even eliminated the subsidies that had already been granted.

31 This Judgement endorsed the constitutionality of Royal Decree-law 16/2012, of 20 April, on urgent measures to guarantee the sustainability of the National Health System and secure the quality of its benefits. SOBRINO GUIJARRO, I. $(2017,84)$. 
hensive position of the Spanish Constitutional Court regarding the cuts in the protection of rights and social principles in times of economic crisis. This can be illustrated by the position adopted by the Portuguese Constitutional Court in Judgment 352/2012, of 5 July, whereby it accepted an appeal brought against Portuguese Law No. 64-B / 2011, of 30 December, of the General State Budget for the year 2012, whereby holiday and Christmas payments to public officials and pensioners were totally or partially suspended due to the profound economic crisis. The Portuguese Court rendered Articles 21 and 25 unconstitutional for violation of the principle of equality. The fifth legal ground stated: ' ... it is indisputable that if the challenged measures were to be implemented, the sacrifices to reduce the public deficit would not be shared equally among all citizens, nor would it be applied proportionally to their financial capabilities, since they would not be universal; instead, they would fall solely on those people who receive their salaries and pensions from public funds (...) therefore only some categories of citizens would be asked to make an additional effort for the benefit of the community from some. ${ }^{32}$

It is obvious that employment is one of the aspects that has been most affected by the throes of the global economic crisis. Unemployment has become a serious problem in Spain, and meeting the goal of full employment contained in Article 40.1 of the Constitution seems to be extremely challenging. But Spain cannot 'throw in the towel', so some policies need to be enacted to promote employment. This is where cooperatives have interesting potential, because their values coincide with a social model that enhances social rights and the guiding principles of social and economic policies, including creating high-quality employment, fostering entrepreneurship and offering some channels for the new forms of work that arise within the so-called models of 'collaborative economy' and 'green work. What follows is a discussion of how the Spanish legal system can help in this regard.

\section{The promotion of cooperatives as a means to support employment policies under the Spanish legal system}

The Spanish legal system provides several forms of support to ensure that cooperatives can go hand-in-hand with employment poli-

32 On this Judgment of the Portuguese Constitutional Court, see: AYMERICH CANO, C. (2015, 364); PONCE SOLÉ, J. (2015, 21-22); SANZ GÓMEZ, R. (2016, 477490); SOTO LOSTAL, S. $(2017,127)$. 
cies, a symbiosis that is certainly favourable to both. DIVAR GARTEIZAURRECOA ${ }^{33}$ has underlined the potential of the 'cooperative alternative' to combat unemployment and poverty. From the point of view of the different legal systems, as pointed out by $\mathrm{FICl}^{34}$ the specific nature of the substantive regime of cooperatives, compared with other types of undertakings is essential in terms of justifying their specific regime in terms of tax and other areas of law, for example.

The Judgement of the Court of Justice of the European Union (First Chamber) of 8 September, 2011 (joined cases C-78/08 to C-80/0835), considered that the Italian law that taxed cooperatives more favourably than for profit undertakings was not necessarily 'state aid' incompatible with European Union law. Also, in the Spanish constitutional case law, the preferential treatment granted by various regulations to cooperatives vis-à-vis other types of undertakings and companies, pursuant to the constitutional mandate to promote cooperatives (as included in Article 129.2 of the Constitution), was supported from the start. This was not only the case for the fiscal area, ${ }^{36}$ but in other very different areas, such as regulations concerning credit unions, ${ }^{37}$ educational regulations, ${ }^{38}$ marine fish farming, etc. ${ }^{39}$

Support to cooperatives cannot go far enough. The UN 2030 Agenda for Sustainable Development advocates full employment, but

33 DIVAR GARTEIZ-AURRECOA, J. (1985).

$34 \mathrm{FICl}, \mathrm{A} .(2015,80)$.

35 As Antonio $\mathrm{FICl}$ explained, the Judgment stemmed from a preliminary question referred to the Court of Justice of the European Union by the Italian Supreme Court of Cassation, as to whether the tax advantages granted by Italian legislation (specifically by Article 11 of Presidential Decree No. 601/1973) for producers' and workers' cooperatives were compatible with EC law. The Italian Supreme Court of Cassation asked if these tax advantages could be considered State aid, contrary to community law. The Court of Justice of the European Union held that it was for the Court that referred the question to '... determine in particular whether the tax exemptions in question are selective and whether they may be justified by the nature or general scheme of the national tax system of which they form part, by establishing in particular whether the cooperative societies at issue in the main proceedings are in fact in a comparable situation to that of other operators in the form of profit-making legal entities and, if that is indeed the case, whether the more advantageous tax treatment enjoyed by those cooperative societies, first, forms an inherent part of the essential principles of the tax system applicable in the Member State concerned and, second, complies with the principles of consistency and proportionality' (paragraph 82 of the Judgment). On this subject, see also, AGUILAR RUBIO, M. (2017, 60 et seq.)

36 ATXABAL RADA, A. $(2008,71)$ and ALONSO RODRIGO, E. (2001, 42 et seq.)

37 STC 155/1993, of 3 May and STC 204/1993, of 17 June.

38 STC 77/1985, of 27 June.

39 STC 103/1989, of 8 June. 
the prevailing economic policies have prioritised balanced budgets, austerity and social cuts. Consequently, cooperatives need to be supported, as they are called upon to play an important role in promoting employment.

That is why Section 6.a of the United Nations General Assembly Resolution 64/136, of 11 February, 2010,40 on cooperatives and social development, urged governments, international organisations and associations that make up this movement to take advantage of and fully develop 'the potential and contribution of cooperatives for the attainment of social development goals, in particular the eradication of poverty, the generation of full and productive employment and the enhancement of social integration'. In a similar vein, the ILO Recommendation No. 193 of 2002 on the promotion of cooperatives ${ }^{41}$ recognised the cooperative contribution to the creation of employment, provided that ' ...the promotion and strengthening of the identity of cooperatives should be encouraged on the basis of: cooperative values of self-help, self-responsibility, democracy, equality, equity and solidarity; as well as ethical values of honesty, openness, social responsibility and caring for others.'

Indeed, cooperatives can serve as an instrument for employment policies from various perspectives: for example, by promoting 'selfemployment', 42 helping to fight mass unemployment, precarious employment and the social-labour exclusion of certain groups of the unemployed. They can also take on some of the social functions that the welfare state is 'failing to fulfil', with the creation of cooperatives in the areas of healthcare, care for dependent and disabled people, financial services (given the struggle for credit), education, renewable energies, cultural activities, agriculture, etc. In this regard, in light of the initiative of the ILO Century project focused on the future of work, the International Cooperative Alliance presented a position paper on the Initial Report of the Global Commission called 'Cooperatives and Future of Work', of 30 April, 2018.43 This paper highlighted the importance of co-

40 Available at http://www.un.org/esa/socdev/documents/resolutions/2009/a-res-64136-sp.pdf (last consulted, 9 May, 2018).

41 Available at http://www.ilo.org/dyn/normlex/en/f?p=NORMLEXPUB:12100:0::NO ::P12100_ILO_CODE:R193 (last consulted, 9 May, 2018).

42 MOLINA NAVARRETE, C. $(2014,56,65-68,75)$. As this author has shown, when there is a such a severe jobs crisis, self-employment, that is, the creation of one's own job through the social economy, especially cooperatives, becomes more important as an option to cover the needs of weakening both of the labour market (labour dimension) and the welfare state (social dimension).

$43 \mathrm{https}$ ://ica.coop/sites/default/files/publication-files/icapositiononfowfinal-1168879467.pdf , pp. 6 and seq. (last seen, 9 May, 2018). 
operatives to create employment, even in the most innovative and dynamic sectors of the economy such as, for example, the 'collaborative economy (and within it, the digital economy), the 'white economy', 'the green economy', 'the circular economy' and the creative industries.

At a time when unemployment continues to threaten our future, we should turn our attention to cooperatives and realise that one of the possible solutions to this challenge has always been readily available, despite not always having been given the attention it deserves. As provided for in the Spanish Constitution, it would be advisable to promote cooperative societies through appropriate legislation (Article 129.2), carrying out policies oriented towards a final goal: full employment (Article 40.1).

\section{Conclusions}

The Spanish legal system defines active employment policies as 'the set package of services and programmes aimed at providing guidance, employment and vocational training for employment in the workplace programmes seeking to improve the employability of unemployed people, either on an employed or a self-employed basis, the maintenance of employment, the professional development of employees and the promotion of entrepreneurship and the social economy'. Given that cooperatives are part of the core of the social economy, the synergy between cooperatives and active employment policies finds a fertile ground for the development of the mandates that the 1978 Spanish Constitution establishes in relation to the promotion of cooperatives (Article 129.2) and a policy aimed at full employment (Article 40.1).

The problem posed by the provisions in Article 40.1 is that their constitutional guarantees are quite weak, given that they do not appear in Chapter II but in Chapter III of Title I of the Constitution, under the heading 'Principles governing Economic and Social Policy'. According to the provisions in Article 53.3 of the Constitution, the recognition, respect and protection of these guiding principles will inform positive law, judicial practice and the actions of the public authorities, but they can only be invoked before ordinary Courts under the legal provisions which develop them. If the legislator fails to develop them or develops them insufficiently, it will be difficult for them to have a practical legal effect that makes them enforceable by the authorities. In addition, the impact of the global economic crisis has brought serious cuts in the benefits derived from some historically recognised social rights and has led to an obvious decline in their levels of protection, as 
a result of the crisis and the 'sacred' principle of balanced budget. And what is worse, the Spanish Constitutional Court (unlike some other Constitutional Courts such as the Portuguese one), has endorsed the constitutionality of these regressive measures.

The promotion of cooperatives is included in Article 129.2 of the Spanish Constitution, which is not contained in Title I (related to fundamental rights and duties), but in Title VII (related to Economy and Finance), which includes most of the provisions of what has been called the 'Economic Constitution'. It is clear that the Spanish Constitution does not intend to have a neutral legislative scenario for cooperatives, but rather clearly opts to support them and create a favourable framework for their development.

As employment is one of the social aspects most severely affected by the global economic crisis, cooperatives provide interesting potential in terms of promoting employment. Recognised by both the UN and the ILO, their values fit a social model that enhances social rights and the guiding principles of social and economic policies, creating high-quality employment, fostering entrepreneurship and self-employment, helping to solve mass unemployment, precarious employment and the social/labour exclusion of certain groups of the unemployed. They even take on some functions that the welfare state no longer covers, with the creation of cooperatives in sectors such as healthcare, care for dependents, education, etc. As stated in the International Cooperative Alliance Report entitled 'Cooperatives and the Future of Work', of 30 April 2018, on the occasion of the ILO Centennial, cooperatives can help to create jobs in the most innovative and dynamic sectors of the economy such as, for example, the 'collaborative economy' (and within it the digital economy), the 'white economy', 'the green economy', 'the circular economy' and creative industries.

\section{References}

ABDELHAMID, A. / AYUSO, M. 2018. Constitución financiera y Constitución social. Valencia: Tirant lo Blanch.

ABRAMOVICH, V. I COURTIS, CH. 2004. Los derechos sociales como derechos exigibles. Madrid: Trotta.

AGUDO ZAMORA, A. 2016. Reforma constitucional y nuevo paradigma del Estado social. De la ordenación contingente a la organización consciente del bienestar. Seville: Centro de Estudios Andaluces.

AGUILAR RUBIO, M. 2016. 'El régimen fiscal de las cooperativas y el Derecho de la Unión Europea'. In Boletín de la Asociación Internacional de Derecho Cooperativo, 50. 
ALONSO RODRIGO, E. 2001. Fiscalidad de cooperativas y sociedades laborales. Barcelona: Institut per la Promoció i la Formació Cooperatives de la Generalitat de Catalunya.

ANSUÁTEGUI ROIG, F.J. 2014. 'Los derechos sociales en tiempos de crisis. Algunas cuestiones sobre su fundamentación'. In BERNUZ, M.J. AND CALVO, M. (EDS.). La eficacia de los derechos sociales. Valencia: Tirant lo Blanch.

AÑÓN ROIG, M.J. 2016. '¿Hay límites a la regresividad de los derechos sociales? In Derechos y libertades'. 34.

ARNÁEZ ARCE, V.M. 2018. 'La alternativa cooperativa en la prestación de servicios públicos sostenibles'. In Boletín de la Asociación Internacional de Derecho Cooperativo, 52, 123-135.

ATXABAL RADA, A. 2008. 'Una propuesta de fiscalidad especial para las Sociedades Mercantiles de Estatuto Cooperativo'. In Boletín de la Academia Vasca de Derecho, 16.

AYMERICH CANO, C. 2015. 'El control constitucional de las políticas de austeridad. Examen de la jurisprudencia portuguesa y española'. In NOGUEIRA LÓPEZ, A. / LOIS GONZÁLEZ, MARTA / DIZ OTERO, I. (Eds.). Crisis, derechos sociales e igualdad. Valencia: Tirant lo Blanch.

BALAGUER CALLEJÓN, F. 2013. 'Una interpretación constitucional de la crisis económica'. In Revista de Derecho Constitucional Europeo, 19.

BARRERO ORTEGA, A. 2017. 'A vueltas con la exigibilidad de los derechos sociales'. In BARRERO ORTEGA, A. (Ed.) Derechos sociales. Lecturas jurídicas en tiempos de crisis. Valencia: Tirant lo Blanch.

BAYLOS GRAU, A. 2003. 'El derecho al trabajo como derecho constitucional'. In Cuadernos de Derecho Judicial, 21.

BELORGEY, J.M. 2016. 'La garantía de los derechos sociales como factor diferencial de Europa'. In INNERARITY, D. / AYMERICH, I. Derechos humanos y políticas públicas europeas. Barcelona: Ed. Paidos.

BONET PÉREZ, J. / ALIJA FERNÁNDEZ, R.A. (Eds.). 2016. La exigibilidad de los derechos económicos y sociales y culturales en la sociedad internacional del siglo XXI: una aproximación jurídica desde el derecho internacional. Madrid: Marcial Pons.

CALVO GARCÍA, M. 2013. 'Crisis económica y efectividad de los derechos sociales'. In MARÍA JOSÉ BERNUZ BENEITEZ (ED. LIT.), MANUEL CALVO GARCÍA (ED. LIT.), . La eficacia de los derechos sociales. Valencia: Tirant lo Blanch.

CARMONA CUENCA, E. 2017. 'Derechos sociales de prestación y obligaciones positivas del Estado en la jurisprudencia del Tribunal Europeo de Derechos Humanos'. Revista de Derecho Político. 100.

CUBERO MARCOS, J.I. 2017. 'La vis expansiva de los derechos fundamentales y su incidencia en la configuración y exigibilidad de los derechos sociales'. In Revista Española de Derecho Constitucional. 110.

DE LUIS ESTEBAN, J.M. 1985. 'Presente y futuro de la fiscalidad de las cooperativas'. In Hacienda Pública Española, 93.

DIVAR GARTEIZ-AURRECOA, J. 1985. La alternativa cooperativa. Barcelona: CEAC. 
DONAIRE VILLA, F.J. 2018. '¿Los derechos en serio en la Eurozona? Los recortes, las condicionalidades, la Carta y el Tribunal de Justicia'. In Revista de Derecho Constitucional Europeo. 29.

EMBID IRUJO, A. 2009. Derechos económicos y sociales. Madrid: Ed. Iustel.

ESCOBAR ROCA, G. 2012. 'Los derechos fundamentales sociales de prestación (doctrina general)'. In ESCOBAR ROCA, G. (Dir.). Derechos sociales y tutela antidiscriminatoria. Cizur Menor. Ed. Thomson Reuters / Aranzadi.

ESPINOSA DE LOS MONTEROS, J. / ORDÓÑEZ, J. (Eds.). 2013. Los derechos sociales en el Estado Constitucional. Valencia: Tirant lo Blanch.

$\mathrm{FICl}, \mathrm{A}$. 2015. 'La función social de las cooperativas: notas de derechos comparado'. In REVESCO. Revista de Estudios Cooperativos. 117.

GADEA, E. / SACRISTÁN, F. / VARGAS VASSEROT, C. 2009. Régimen jurídico de la Sociedad Cooperativa del siglo XXI. Realidad actual y propuestas de reforma. Madrid: Ed. Dykinson.

GAMBINO, S. 2017. 'Estado social y crisis económica. Los nuevos desafíos del constitucionalismo contemporáneo'. In Revista de Derecho Constitucional Europeo. 28.

GARCÍA HERRERA, M.A. 2003-2004. 'Veinticinco años de derechos sociales en la experiencia constitucional española'. In Revista de Derecho Político, 58-59.

GARCÍA SCHWARZ, R. 2011. Derechos sociales: imprescindibilidad y garantías. Cizur Menor: Ed. Thomson Reuters.

GORDILLO PÉREZ, L.I. 2014. 'Derechos sociales y austeridad'. Lex Social. Revista Jurídica de los Derechos Sociales. 1.

GORDILLO PÉREZ, L.I. 2015. 'Consideraciones sobre los derechos sociales y sus garantías'. In Zúñiga, V. I Córdoba del Valle, Ed. (Dirs.). Derechos sociales. Políticas públicas, exigibilidad, justiciabilidad. Valencia: Tirant lo Blanch.

JIMENA QUESADA, L. 2014. 'La protección internacional de los derechos sociales y laborales'. In Revista de Derecho Social. 65

JIMENA QUESADA, L. 2016. 'Vectores y pilares básicos del modelo social europeo'. In INNERARITY, D. I AYMERICH, I. Derechos humanos y políticas públicas europeas. Barcelona: Ed. Paidos.

JIMENA QUESADA, L. 2017. Devaluación y blindaje del Estado social y democrático de Derecho. Valencia: Tirant lo Blanch.

LANGFORD, M. (Ed.) 2009. Social Rights Jurisprudence. Emerging Trends in International and Comparative Law. Cambridge: Cambridge University Press.

LARRAZABAL BASAÑEZ, S. 2009. 'Constitución económica, democracia social, innovación y cultura económica del cooperativismo vasco'. In Boletín de la Asociación Internacional de Derecho Cooperativo, 43.

LÓPEZ GARRIDO, D. (Dir.). 2013. Reforma constitucional y estabilidad presupuestaria. El artículo 135 de la Constitución española. Madrid: Centro de Estudios Políticos y Constitucionales.

MARTíNEZ DE BRINGAS, A. 2018. 'Los derechos sociales ante la vulnerabilidad social. Retos y problemáticas en un marco de flexibilidad y desregulación de los derechos. In Revista Vasca de Administración Pública'. 111. 
MOLINA NAVARRETE, C. 2014. 'Las cooperativas como forma alternativa de creación de puestos de trabajo: el empleo cooperativo entre mitos y realidades'. In Revista General del Derecho del Trabajo y de la Seguridad Social. 37.

MONEREO PÉREZ, J.L. 2013. 'Crisis económica y reforma laboral en la larga duración histórica'. In Teoría y Derecho: Revista de pensamiento jurídico, 13.

MONEREO PÉREZ, J.L. 2016. 'Las políticas activas de empleo, derecho al trabajo y políticas activas de empleo en el marco de la política de empleo'. In MONEREO PÉREZ, J.L. / FERNÁNDEZ BERNAT, J.A. (Eds.) Las políticas activas de empleo: configuración y estudio de su regulación jurídica e institucional. Cizur Menor: Thomson Reuters Aranzadi.

MONEREO PÉREZ, J.L. 2017. 'Por una teoría general de los derechos sociales fundamentales que garantice su plena efectividad'. In Derecho de las Relaciones Laborales, 8

NOGUERA FERNÁNDEZ, A. / GUAMÁN HERNÁNDEZ, A. 2014. Lecciones sobre Estado Social y Derechos Sociales. Valencia: Tirant lo Blanch.

PÉREZ LUÑO, A.E. 2013. 'Aproximación al análisis conceptual de los derechos sociales'. In MARÍA JOSÉ BERNUZ BENEITEZ (ED. LIT.), MANUEL CALVO GARCÍA (ED. LIT.), . La eficacia de los derechos sociales. Valencia: Tirant lo Blanch.

PISARELLO, G. 2007. Los derechos sociales y sus garantías. Elementos para una reconstrucción. Madrid: Trotta.

PISARELLO, G. 2009. 'La justiciabilidad de los derechos sociales en el sistema constitucional español'. In PISARELLO, G. / GARCÍA MORALES, A. / OLIVAS DÍAZ, A. (eds.) Los derechos sociales como derechos justiciables: potencialidades y límites. Albacete: Ed. Bomarzo.

PONCE SOLÉ, J. 2013. El derecho y la (i)rreversibilidad limitada de los derechos sociales de los ciudadanos. Las líneas rojas constitucionales a los recortes y la sostenibilidad social. Madrid: Instituto Nacional de Administración Pública.

PONCE SOLÉ, J. 2015. 'Aproximación al análisis conceptual de los derechos sociales'. In Revista de Derecho Constitucional Europeo', 23.

PONCE SOLÉ, J. 2017. 'Reforma constitucional y derechos sociales: la necesidad de un nuevo paradigma en el Derecho Público español'. Revista Española de Derecho Constitucional. 111.

PONS CARMENA, M. 2015. Modelo social europeo y protección de los derechos sociales fundamentales. Madrid: Ed. Reus.

PRADOS DE REYES, J. / VIDA SORIA, J. 1998. 'Comentario al artículo 129 de la Constitución'. In ALZAGA VILLAAMIL, O. (Dir.) Comentarios a la Constitución Española de 1978. Madrid: Cortes Generales / Editoriales de Derecho Reunidas (EDERSA), $X$.

PRESNO LINERA, M.A. (Ed.). 2010. Los derechos sociales como instrumento de emancipación. Pamplona: Ed. Aranzadi.

QUEIROZ, C. 2006. O Princípio de nao Reversibilidade dos Direitos Fundamentais Sociais. Princípios Dogmáticos e Prática Jurisprudencial. Coimbra: Coimbra Editora. 
REQUEJO RODRÍGUEZ, P. 2015. 'El papel de la crisis económica en la argumentación del Tribunal Constitucional. Comentario a la STC 119/2014'. In Teoría y Realidad Constitucional, 36.

RODRIGO, A. 2016. 'Los derechos sociales en tiempos de crisis económica y el desarrollo sostenible'. In ABAD, M./ LLAMAZARES, M.C. / RODRíGUEZ, E. (Dirs.). Politicas económicas y derechos sociales. Madrid: Dykinson

RUIZ-RICO RUIZ, G. 2016. Los derechos sociales en el Estado Constitucional. México: Ed. Porrúa.

SANZ GÓMEZ, R. 2016. 'Límites constitucionales a los ajustes presupuestarios: las reducciones en los salarios del sector público. A propósito de la Sentencia del Tribunal Constitucional portugués 431/2014'. In Crónica Jurídica Hispalense, 13.

SANZ GÓMEZ, R. 2017. 'Los derechos sociales ante la crisis de las finanzas públicas: asimetrías normativasC. In BARRERO ORTEGA, A. (Ed.) Derechos sociales. Lecturas jurídicas en tiempos de crisis. Valencia: Tirant lo Blanch.

SOBRINO GUIJARRO, I. 2017. 'Contenido constitucional del derecho a la protección de la salud a la luz de la STC 139/2016'. In lus et Scientia, 1.

SOTO LOSTAL, S. 2013. 'Regresividad, derechos constitucionales y Estado social'. In Revista de Derechos Sociales, 3-2.

SOTO LOSTAL, S. 2017. 'La exigibilidad de los derechos sociales frente a su restricción regresiva'. In BARRERO ORTEGA, A. (Ed.) Derechos sociales. Lecturas jurídicas en tiempos de crisis. Valencia: Tirant lo Blanch.

TAJADURA TEJADA. J. 2002. 'La inconstitucionalidad por omisión y los derechos sociales'. IN CORCUERA ATIENZA, F.J. La protección de los derechos fundamentales en la Unión Europea. Madrid: Dykinson.

TENORIO, P. 2012. 'El Tribunal Constitucional, la cláusula del Estado social, los derechos sociales y el derecho a un mínimo vital digno'. In AUTORES VARIOS (2012). Derechos sociales y principios rectores. Valencia: Tirant lo Blanch.

TEROL BECERRA, M. 2009a. Los derechos sociales en el siglo XXI. Valencia: Tirant lo Blanch.

TEROL BECERRA, M. 2009b. 'La España de los derechos sociales en las Europeas vista desde las reformas estatutarias'. In Revista Europea de Derechos Fundamentales, 13.

TEROL BECERRA, M. / JIMENA QUESADA, L. 2011. 'Reflexiones sobre la constitucionalización de los derechos sociales'. In Teoría y Derecho: Revista de Pensamiento Jurídico, 9.

TEROL BECERRA, M. 2012. 'Treinta años de desarrollo constitucional y legislativo de los derechos sociales: derechos ciudadanos y principios rectores'. In CASCAJO CASTRO, J.L. "et al.". Derechos sociales y principios rectores. Actas del IX Congreso de la Asociación de Constitucionalistas de España. Valencia: Tirant lo Blanch.

TEROL BECERRA, M. / JIMENA QUESADA, L. (Dir). 2014. Tratado sobre protección de Derechos sociales. Valencia: Ed. Tirant lo Blanch.

TORNOS MÁS, J. 2017. 'Derechos sociales, Comunidades Autónomas y crisis económica. Las políticas autonómicas en materia de vivienda'. Revista Valenciana d'estudis autonómics. 62. 
TORROJA MATEU, H. 2016. 'El control internacional universal cuasi contencioso de los derechos económicos, sociales y culturales: comentarios a la comunicación $n^{\circ}$ 2/2014 ante el Comité de Derechos Económicos, Sociales y Culturales sobre el incumplimiento por el Estado español del derecho a una vivienda digna'. In BONET PÉREZ, J. / ALIJA FERNANDEZ, R.A. (Eds.) (2016), La exigibilidad de los derechos económicos y sociales y culturales en la sociedad internacional del siglo XXI: una aproximación jurídica desde el derecho internacional. Madrid: Marcial Pons.

TUSHNET, M. 2008. Weak Courts. Strong Rights. Judicial Review and Social Welfare Rights in Comparative Constitutional Law. Princenton: Princenton University Press.

VALCÁRCEL BUSTOS, M.T. 2018. 'Competencias y reconocimiento de las personas vulnerables: sanidad, vivienda y derechos fundamentales. In Revista Vasca de Administración Pública, 111.

VALDÉS DAL-RÉ, F. 2016. El constitucionalismo laboral europeo y la protección multinivel de los derechos laborales fundamentales: luces y sombras. Albacete: Ed. Bomarzo.

VALDÉS DAL-RÉ, F. 2018. 'Constitucionalismo laboral europeo'. In Lefebvre. F (Ed.). Derecho social de la Unión Europea. Aplicación por el Tribunal de Justicia. Madrid: Francis Lefebvre. 


\section{Derechos de autor}

El Boletín de la Asociación Internacional de Derecho Cooperativo es una revista de acceso abierto lo que significa que es de libre acceso en su integridad inmediatamente después de la publicación de cada número. Se permite su lectura, la búsqueda, descarga, distribución y reutilización legal en cualquier tipo de soporte sólo para fines no comerciales y según lo previsto por la ley; sin la previa autorización de la Editorial (Universidad de Deusto) o el autor, siempre que la obra original sea debidamente citada (número, año, páginas y DOI si procede) y cualquier cambio en el original esté claramente indicado.

\section{Copyright}

The International Association of Cooperative Law Journal is an Open Access journal which means that it is free for full and immediate access, reading, search, download, distribution, and lawful reuse in any medium only for non-commercial purposes, without prior permission from the Publisher or the author; provided the original work is properly cited and any changes to the original are clearly indicated. 